like to ask tlu' speaker just how casen of shock cone off from the operating table.

Miss Dancr.--We do not have them; we prevent them. Prevontion is the letter part of cure. $11 \%$ ure taught what to do in case one should necur. W" apply a compress and then a bandage is put over that and drawn tight. At. the same time a hot pack is given to the hips and legs and an iee pack is put wr the henrt. We do not get eases of shoek, we prevent them.

IIss Colnkiris.--Although 1 have been trained to he an exponent of the old school, I have seen an almont expiring patient respond as quickly to the application of a hot towal as he would to a hypodermie of ether. I should have sald the hot towel was applied over the lienrt.

Miss Axnd (. Jammf.-At the Viyo brotlers' hospital they rarely give a heart stimnlant, they depend cutirely on the saline aiter operation. We rarely have shock, and I do not believe the boctors Mayo ever give a hypodeinic, they depend entircly on the saline solution for a leart stimulant.

NIRS. Ronn.-That form of treatment is not confined to the Doctors Mayo; it is general.

Miss Dascr.-When 1 was with Dr. Murplyy wr used the hot siling by the llop methon and found it very beneficial.

\title{
THE LIMITATIONS OF THE NURSING PROFESSION
}

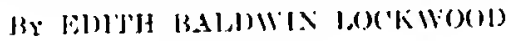 \\ (iranby. collu.
}

Ix considering the limitations of the nursing professinn, we may in a general way elassify them as those neessiry to the profession's levelopment and those restrictive to its developinent, or, to elassify differently, we have: the limitation of origin, the limitation of purpose; the limitation of our sistem of edueation: and the limitation of our fielul of endearol. These are to some extent eorrelatel and interlependent and do not separate exintly according to the terms of the first elassifieation.

The origin of the profession and the purpose of the origin impose distinetly different obligations. The origin was most humble, the purrose most noble. 'The origin was in the change from the erude, grossly negleetful attendance on siekness.--altendanee that was eonsidered the most menial and decrated form of personal service,- to attendance. having humane handling and simple cleanliness as its object. The purpose aetuating those who instituted this ehange was no more, nn less, than the purpose of the profession to-day. If, in the strength of that purpose, it has grown in a seant half century from its origin in humble degraded service to the aceepted rank of a profession, we muat accept without rhallenge the scope of that purpose as imposing $\mathrm{n} n$ limitatinne we may unt well areept to-ray. 
In considering these linitations I do not wish to imply that we have reached our ultimate development. The progress that has been made is from nothing to a profession. The line of progress before us is from " profession on to a scicnce. But the time may not be quite ripe, as I think a comsideration of our limitations will show. Progress has been rapid, asy, and spectacular, but it is possible, and I think inevitable, that there is a period of work, of hard, self-saerificing work, not less than that done in the heginning, before the profession is so perfeeter as to he ready for furtlier progress. Filling in the chinks, putting in new sills, or squaring up the underpinning is neither in agreeablo or as showy work as adding a new story, lut it is more essential to the stability of the structure.

It is somewhat dillicult to formulate a definition, which shall bo a complete, concise statement of the purpose of mursing. The following, perhaps, is an approach to it: to establish and maintain such condition of person and surroundings that the disconfiture incident to illnes: be borne with i mininum of distress, and fo administer sueh remedies and trentment for the alleviation of suffering, and the removal of the eause of illness, as are ordered by the medical profession. 'This spplies to nursing. If' I make the definition me the purgose of the mursing profession I must ard: and to do this in a professional mammer. As I grive it first, it might apply to paid menisl service; with this chuse adfed it implies the dignity and responsihility of a pro. linsion. quadrupling the requirements.

The definition is fairly comprehensive and applies equally well to the purpose of the indiridual nurse, the provine of the nursing force in an institution, and to the profession as a whole, and with practically no exeeption the profession's present rightful field of endeavor is envered by it. The task of making the profession fulfil the requirements of that definition is one so great that all energy generated by our nursing organizations may well be direeted thereto.

From this vicwpoint of the profession's purport, some of the eommon questions frequently propounded kem incignifiranf as well as irrelevant. Such a question for instance as. "Shall the murse prescribe?" We have bit to look at our purpose pror answer. "But" asked some one reeently, "may she not as much as preseribe a Seidlit\% powder for a headaehe?" Certainly not; if she is in the relation of nurse to patient, with a doetor in charge of the ease. It is a human prerogative to advise the fellowman what to do for his eold or his dyspepsia. The non-professionnl does it, and the professional nurse will and may do it,-as a fellowman...-hut not in a profecsional capacity 
wlay she prescribe or administer the simplest medieinal remedy on her own initiative. The latitude a doctor may grant a nurse in this respect is to be used as part of her orders, but latitude allowed in one ease should never be assumed in another without full understanding, and latitude allowed by onc doctor should never be assumed under another. Dr. Hugh Cabot has said that the time may eome when "that part of medicine which is absolutely settled and worked out" may be given to the profession of nursing as its rightful field. But you will all agree that the time is not yet. This limitation is one that we should respeet and adlere to literally. The letting down of one bar, the granting or assuming a privilege is franght with grave danger. With the material forming the rank and file of the profession what it is, the granting of an ineli means the taking of the proverbial ell.

The present method of edueating a nurse, of preparing a woman for a profession is not a limitation merely, it is more even than a positive lindranec; it is a retrogressive foree. 'The fonndation of teaching nursing was necessarily in keeping with the humbleness of its origin, but from this origin of the system of teaching has eone no udvance in keeping with the growth of nursing. In all other fields of edueation we have grown away from the apprenticeship system. In the trades, even, schools for teaehing the trades linve been instituted. 'The professions have each their special college or department of a mniversity, while nursing, grown to a profession, still educates its pupils by the apprenticeship system instituted at its origin.

'To liken our profession to a plant, it has grown rapidly, exuberantly, but unevenly, It las grown weakly in plaees ind needs reinforcing; while in other places it needs pruning. It has nuterown its root room and needs transplanting to soil suitable for its better development.

The present training-sehool systen has just the same root room as the initial seed of edueating nurses was planted in. We have tried througl organization and legislation to "elevate the profession." We have tried through raising the entranee requirments and hy all clalmrated eurriculum to raise the standard. We have iried thronish the eourse at Columbia College to provide a means of better instruction in the schools; and with what result? Sot inconsiderable or insignificant perhaps, but still out of proportion to the arlvanee to a profession in the earlier years. It is as if we were tying little pieces of lath on the weak stalks of the plant or tying up the wilted overgrowths when the plant needs transplanting.

To drop the metaphor. Just what does transplanting the plant menn? It means the estahlishment of seliools for teaching the pro- 
fession of nursing - schools that are educationil justitulions in themselves, and only that. It neans further the disestablishment of existing. schools which are maintained wholly, or in part, for other purposes than teaching how to cale for the siek. 'The training sehool of to-day' is, as it was in the berimning. " lepartuent of the hospital, nsed by the hospital to take care of the sick. 'The trainimg sehool should he an institution for teaching how to care for the sick and I think befor. we can reach full or further derelopment must come the recognition that teaching how to eare for the sick is a scparate distinct proposition, not of equal or greater or less importance than the carce wl the sick.

The eare of the sick is the hospital's putpose; its problem to solve. The teaching of nursing is the training scheol's purpose, its problem in. solve. If the hospital and seliool are one it his two problems of independent nature and ralue and it is in 10 way justitied in solving one at the expense of the other.

I think no one las erer alvanced the shortage of gladuate nurkes in a reason for a short course, a low entranee requirement. of a simplifier currieulum. It is the shortage of probationers, the shortuge of sufficient pupils in the sehool to take eare of the siek in the hospital, to to the hospital's work. That is undisguisedly the reisoll for the " returu to the two years' eourse" of which we have heurd so unuch. It would be rather absurd if a normal sehool for teachers shonld insist on entollinir students enough to teach the public schools of a city. hut the case i= a perfect analogy.

What should be required in a woman to make hej wortly of entering the profession of nursing? I think we at once concerle that there must be mental, moral, physieal, and edueational and temperamental fitness and that the absence of any one of these is, if not sufficient to debar, at least a very serious drawback to her eligibility.

An illustration from actual experienee in the training sehool will not only sound familiar to teachers of nurses hut will show elearly the detrimental results of the system; the limitation it is to the profession's development. 'The prineiple of instruction for probationers is in many schools: "Teach them what will most quickly make them of value in the wards. Teach then practically, how to do tlings that need to be done, the theory to be taught later. For instance: Teach the preparation of eatheter and douche trays; the principles of asepsis and sterilization to be taught in the second year. Teach hospital etiquette; give instructions in ethics, ete." I have in mind one class of sixteen probationers. In review. I think about six were competent to be arlmitted to a nurses training. There were women there who didn't 
know "hether "ethics" was a disease or a river in Africa; women to whom the difference between one-thirtieth and one-sixtieth was the pons "sinorum of mathematics. 'I'he teacher of this class was reminded that ethices was to be tanght to probationers, and when she answered that they were struggling with common fractions, was told, that having heen a teacher she was prone to lay too much stress on primary mofieieney:

At the elose of her first probatiohary month one of these pupils was reported as alssolutely incompetent and unfit for further trial. But, it wals said, the number of nurses must be kept up, and there Was not another applieation on hand. "We must wait," said the -uperintendent, "and weed her out wheu conditions are more favorable." $s_{(1)}$ they put her on uight duty in the elironic ward to get her out of sight, and the weeding-out time came when she gare an ounce for a ilatchun of a sedative mixture.

We can legislate and registrate until the chapter's end, but we meser with be a profession or at scienee mitil this sort of thing is absoIntely eliminated. Until we cin sceure students worthy of professional instruetion, we may well be chary of assertions that ours and the medical jrofession should meet on equal footing.

I spoke of some of the limitations we should respect in our relation to the medicul profession. There wonld seldom if ever be need to eall attention to this or to eriticize, it only women of suitable qualifications were in the profession. 'The lack of recognition of what is professional in the various relation of nurse to loctor, to patient, to employer, and to fellow murse is the direct cause of the thonsand and one complaints against us as a class and as individuals.

A profession is an oeeupation involving speeial fitness, special dis(ipline and specinl instruetion. The special fitness is edueation, and miluention of more than one generation, the heritage of mental and moral training. "Profession" is synonymous with voeation, ealling: and art, and carries both obligation and limitation that a trade, or work-nceupation for a livelihood-does not carry.

I think there is no limitation to what may be done, and done in ") professinnal manner. A man who throngh long months under professional eare observed our representatives with interest said: "If the nurse says ' $I$ am gning to ent your toe-nails now,' then it's professional, but if I say to her. 'I want you to eut my toe-nails now' that makes it nenial servire." It mas jestingly, perhaps coarsely, put but I think he lonched the kernote. It is the manner of approach to the work. 'The professional nurse does not take orders from employer or patient, 
but lrom the doctor unly. She is in elarge of all that pertains to the patient's welfare, other than the doetor's province.

I take very little stock in the cry of the over-trained nurse; she who knows so mueh she won't do anything. She is very apt to be the woman of inferior quality who was necessary to keep up the number required by the hospital; sle has attained a smattering of technieal terms and professional ideas which she is imable to assimilate and the result is the over-trained nurse. Verily i little learning is a dangerous thing. Once proemre the eondition where only such women us possess sound fundamental requirements are allowed to study nursing and the over-trined nurse will cease to be.

The linitation of what may be done in the individual case cimmot be established by abstrnet rnling. It must be deeided by eaeh nurse in aceordance with eireumslances, and is it not requisite that she possess this rery essential profistional seme? and that the output of sehook of nursing should glarantec it? It the carrying ont of the profession' jurport involves manual lalkor and persomal service it does not relegate nursing to their rank, hut elevates them rather, in sneh degree as they form a part of the end to be attained to the rank of a profession.

In the practice of a profession the end songht, the purport, is something other than finincial return. Work for the work's sake must ilway's be the attitute of prolessional service, in contrast to exchange for an efpivalent value in money or in trade. For neel confusion arise because "work for the worli"s anke" reeeives a noney compentsation. The question of the moncy value of a nurses service is one I wish to tonch but briefly, just enough to say we must aroid any and everything that suggests trades-union priuciples. Let the eharge be a matter of husiness between the nurse and her employer, and as a business anreement inviolate. With the true professional sense should $\left.g^{\prime}\right)$ a practieal rense of business honor-too often laeking. not only in nur profession but in our sex. The establishment of a sliding scale of charges as a solution to the problem of supplying nursing to the great. iniddle class is a beautiful theory, lut who shall set the ware of the individual nursur for the individual ease? Who shall adjust the seale? It would repuire jurlge, jury, and superior court in one embodiment. The nurse has a lart, a share, in many forms of the world's endeavor for the betterment of mankind, but only as a factor. The problens do not beeome the profession"s responsibility. "The Care of the Great Middle Class" is at problem in which our profession is a factor, necessary for its solution, but it is not a problem for us to solve. It is, to be sure, a liunanitarian obligation but it is a municipal or civie duty, shated by us only als ritizens. 
It is rather absurd, is it not, to be investigating almshouses, instructing public health committecs and planning to take care of the great middle class while we are not working to conclusions in our own affairs. Let us look to our own interests, recognize our limitations, correct our own faults. Let us work to conelusions and effects in schools for nurses so that the next generation of nurses shall have a surer, broader footing on which to stand and call itself a profession, ancl ensier steps upward to a science.

This has all been put before you in varying forms during the convention. Adopting resolutions and instructing committees sound well in the rcports but what is going to be done? Before The University of Minnesota shall lave graduated five nurses from this its most admirable system of teaching nursing, schools the country through will have turned out five hundred and fifty-five incompetent, incapable graduates, detriments to the profession.

It is only onc sniall thing to arrange a perfect training-school system. It is another larger and morc serious problem to check the output of incompetents. Turning a small stream into a large river will not alter its character to an appreciable degree. We must go to the source and perfect the character of the supply in order to have a worthy outflow. Intcresting as are the world's endeavors, important as is our profession's pirt in thcm, let us not lose sight of the fact that first we must perfect ourselves.

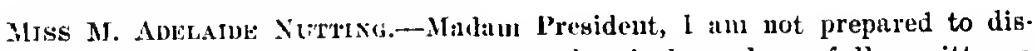
cuss this piper. It is altogether too comprehensively and carefully written a puper to be discussed without some preparation. I feel only that with the general import of it, which states emphatieally and distinetly the need for improvement in our. systeu, 1 an in entire sympathy. Suggestion after suggestion has been made of thr greatest value. No one has ever met a more difficult complieation. It will need nany papers to discuss the needs of this question. I do not believe the government of the United States faces anything more difficult than the training sehool in the hospital. We are not here in antagonism to the hospitals you rcpresent. We know the system we represent has improved with the most painful and serious eflort. No one who has not been a superintendent of a training sehool for many years knows under what conditions and under whit diffieulties every step of improvement has been reached. I am thoroughly of the opinion that the sehool should do all the work. We have a long way to go before we establish that in the pupil's mind. In nearly all the pupers we have had, the paper by Miss Hay, the paper by Dr. Beard, and the paper by Mrs. Lockwood, the keynote was better education of the nurse, and without that your education eannot be what it ought to be.

I do not agree with Mrs. Lockwood in all respects, for we have the powel and the strength to assist those who are struggling with the problems of alnıshouses and insane asylums. 
Unte thing I would like to emphasize, and that is the need of working logether in the litmost harmony ior the utmost effect in the work we love and cherish. No une ann to it alone, but I plead for the elosest harmony of all the nurses.

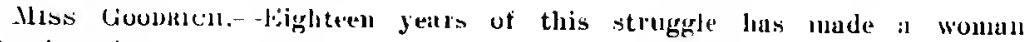
nullingist of me.

Miss fock.- I would like to emphasize the point made regarding the sliding ralle. I quite agree that the sliding seale ean never be a matter for the individual nurse to struggle with. I believe if suel a thing enu be evolved it can onty be evolved through organizations. I believe the average woman amot safely undertake the mingement of the sliding scale. The main teature whieh lies at the bottum of all trade organizations is brotherhood, and I want (1) point ont that the sliding seale is dangerous ior the individual woman to

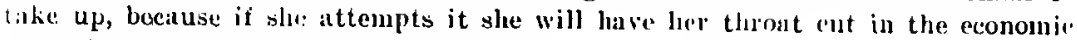
trugrgle and she will sink into poverty.

Mrss S.virl,--In the modern system of training schools as wo have theu now, duay I ask low many patients one nurse showld be expected la care for in private hospitals and likewise in public wards?

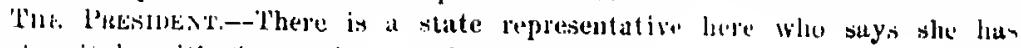

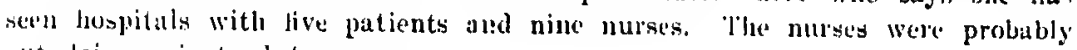
wit doing private duty.

Miss sarda. - In connection with that question it ocenrs to me we might. take into eonsideration what nuses are expected to do. On the ride last even. iner on vur cal the remark was made by some one that in the western small lowns the little things necessary to be clone for patients in our large eities are not expected of the nurse, and lence the murse is alste to take cirre of more pittients than in ond large city hospitals. I mean patients iu private rooms.

IIIss Nul"rixi.-IIay l ask who does the "littlo things" for patients?

Hiss Surri.-They are not done. What 1 mesn is taking eare of flowern, brusling the hair. and things of that sort done for unr anistocratie patients.

Miss: Nuprixi, - I conmider brushing the hajl one of the fine arts.

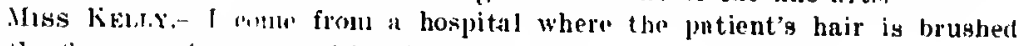
atul the flowirn taken cance of by the nurse.

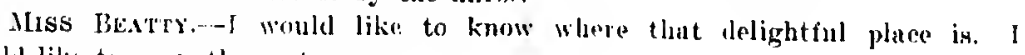
would like to move the lie at onee.

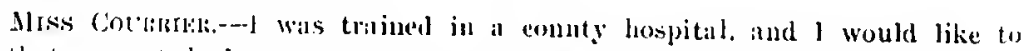

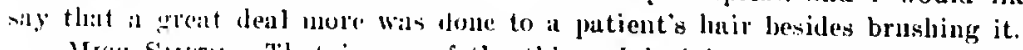

Mrss Sment- That in ane of the things I lad in minel amd was the reason 1 raiked tir question.

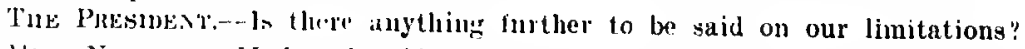

Hass Nurravg.-Machan l're-ident. Wr ate all painfully eonseions of them.

Mas. Lockwoun.-- In view of what Miss Nutting said I to not minimize the importance comacience pliys in publie health, lut $I$ do feel the need of home tuty first. These things are sceondary duties of ont profession. The perfeetion of our profesiou comes abov these other very important essential things. We ("ull do bettes work for them after we are more able to work.

Miss NuTTiva.--1 make in apology now for speaking agaill and promiso unt to say alything iurther. I only wish to say that careful application to

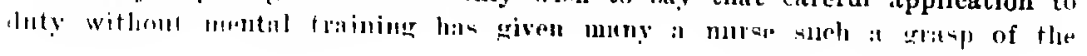


sitnation that it has enabled her to Hct without specitic instruction. Nor would I except the hospital training. I realize how splendid is our own hospital training; we do not get it anywhere clse. Our own homes have failed to give it to us, and we need it in our work inside and outside the home. I would, lowever, check some of the abuses that are entering into that training. I would shorten the hours, I would make the surroundings as good as possible, and I would nake the standard of training higher, but I would not slorten the coursi of training. Other educational bodies are lengthening their courae of training.

\section{THE NURSE AS AN ANÆSTHETIST}

\section{BI FLORENCE HENDERSON,}

Aursthetist to St. Mary's Hospital, Rochester, Minnesota.

Is the nursing profession, as in all other lines of work, the tendency if the day is toward specialism, and by this means more effieient work is being aecomplished. In the different branelies each nurse can find the line of work which is particularly adapted to her abilities, and by coneentrating ler energies she will attain a degree of skill in one direetion which it nould bo impossible to acquire in all. A fow years ago there were comparatively few things for a nurse to choose from, asicle from private duty and a few hospital positions. when she had completed her lospital traiming. Now new arenues are opening eneh year and nurses are being called upon to take more responsible duties.

One special work which is not new, but which is being taken up ly nurses more and more, is the giving of aniesthetics. Ill some hospitals anesthetice have been given by nurses for years. In a great many, where the highest standards are maintained in crery other depariment, this work is assigned to the youngest interne. who has had less instruction in this brancl than in any other in his medical eourse.

More and more surgeons are coming to realize the importance of laving a regular anæsthetist, and that it is profitable to develop a competent one from a well-trained surgieal nurse, who will beenme proficient from steady employnent. Very few physicians who give anæstheties expect to continue this work: therefore. the loctor anas. thetist's attention is divided hetween the anæsthetir and the operation, as that is where his interest lies. As a result, the surceon must rivide his attention between the operation and the nareosis. With the nurse it is different. She never expeets to be a surgeon and her whole attention is concentrated upon the welfare of the patient.

At the present time ether is the standard anæsthetie, and the nurse who gives anæsthetics should become an ether speeialist and should work wher ether is used practically exclusively. Chloroform. spinal 